\title{
POTASSIUM AND SODIUM OF RED BLOOD CELLS IN SICKLE CELL ANEMIA ${ }^{1}$
}

\author{
By D. C. TOSTESON, ETHEL SHEA, AND R. C. DARLING \\ (From the Department of Medicine, College of Physicians and Surgeons, Columbia University; \\ and the Presbyterian Hospital in the City of New York)
}

(Submitted for publication December 15, 1951 ; accepted February 5, 1952)

Normal human red cells contain approximately $100 \mathrm{mEq} . / 1$. of potassium $(\mathrm{K})$ and $10 \mathrm{mEq} . / 1$. of sodium $(\mathrm{Na})$. The $\mathrm{K}$ composition of sickle cell anemia (hereinafter designated SCA) red cells was first investigated by Erickson and her coworkers (1) who found that red cell [K] in SCA was approximately $10 \%$ less than normal red cell $[\mathrm{K}]$.

Our interest in the distribution of cations in SCA blood was stimulated by the observation of elevated venous serum $[\mathrm{K}]$ in three patients with SCA. Erickson and her co-workers did not report what effect varying blood oxygen content had on [K] and [ $\mathrm{Na}$ ] in SCA red cells. Since oxygen is known to affect other properties of SCA red cells $(2,3)$, it was decided to investigate the effect of controlling this variable. Therefore measurements of SCA red cell [ $\mathrm{Na}$ ] and [K] were made in both oxygenated and de-oxygenated states, in vivo and in vitro.

\section{METHODS}

\section{Analytical techniques}

$\mathrm{K}$ and $\mathrm{Na}$ were measured with a barrier layer cell flame photometer operated with a lithium internal standard (4). It is estimated that these measurements are accurate to $\pm 2 \%$. When measured, water content of the red cells was determined by weighing a sample before and after drying in an oven at $110^{\circ} \mathrm{C}$. for 24 or more hours. In some instances, $\mathrm{pO}_{2}$ and $\mathrm{pCO}_{2}$ in the gas phase of the experiments were measured by the method of Scholander (5), and the $\mathrm{O}_{2}$ and $\mathrm{CO}_{2}$ content of the blood phase by the technique of Van Slyke and Neill (6). The red cells for $\mathrm{K}$ and $\mathrm{Na}$ analyses were pipetted by syringe suction with an Ostwald pipette calibrated to contain the desired volume.

\section{Experimental procedures}

(a) Short term experiments in vitro. Forty to fifty $\mathrm{ml}$. of blood were drawn from the antecubital vein of nor-

1 This research was aided by a grant to Columbia University from the Baruch Committee on Physical Medicine and Rehabilitation. mal subjects and patients with SCA. The blood was immediately heparinized with approximately 50 cat units of crystalline heparin per $10 \mathrm{ml}$. blood. Within one-half to one hour, $15-20 \mathrm{ml}$. of this heparinized venous blood were placed in each of two Barcroft tonometers $(300 \mathrm{ml}$. capacity), one containing $30 \% \mathrm{O}_{2}-5 \% \mathrm{CO}_{2}-65 \% \mathrm{~N}_{2}$, and the other containing $0 \% \mathrm{O}_{2}-5 \% \mathrm{CO}_{2}-95 \% \mathrm{~N}_{2}$. The tonometers were sealed with $\mathrm{Hg}$ and rotated at $20 \mathrm{rpm}$. in a water bath at $37^{\circ} \mathrm{C}$. for $20-30$ minutes. The blood was then removed under oil and, in some instances, whole blood samples taken for gas analysis. The remainder of the blood was centrifuged under oil at $14 \times 10^{3} \mathrm{~g}$. for one hour, after which samples of plasma and red cells were taken for $\mathrm{K}, \mathrm{Na}$, and water analysis as indicated.

In order to test the reversibility of the cation changes observed in the experiments described above, a $60 \mathrm{ml}$. sample of fresh heparinized venous SCA blood was first deoxygenated by equilibration for one-half hour in a Barcroft tonometer at $37^{\circ} \mathrm{C}$. with $95 \% \mathrm{~N}_{2}-5 \% \mathrm{CO}_{2}$, as before. Then a $20 \mathrm{ml}$. sample was removed for analysis, the gas phase was flushed out with $95 \% \mathrm{O}_{2}-5 \% \mathrm{CO}_{2}$ and the remaining $40 \mathrm{ml}$. of blood re-equilibrated for one-half hour with this gas. Next, a second sample was taken out, the final $20 \mathrm{ml}$. of blood were again deoxygenated by equilibrium in $95 \% \mathrm{~N}_{2}-5 \% \mathrm{CO}_{2}$. This blood was then the third sample. All blood samples were collected and centrifuged under oil at $800 \mathrm{~g}$. for five minutes and plasma samples taken. The remaining loosely packed red cells were then centrifuged at $14 \times 10^{3} \mathrm{~g}$. as before, the remaining plasma removed, and red cell samples taken for measurement of $\mathrm{Na}, \mathrm{K}$, and water content.

Since carbon monoxide prevents the occurrence of sickling of SCA red cells in a hypoxic medium (2), it was decided to utilize this fact to study the effect of hypoxia on cation changes in the absence of sickling. Forty ml. of fresh heparinized venous SCA or normal blood were gently shaken in a flask containing approximately $25 \% \mathrm{CO}-72 \% \mathrm{~N}_{2}-3 \% \mathrm{CO}_{2}$ until cherry red in color. Twenty $\mathrm{ml}$. samples of this blood were then placed in each of two Barcroft tonometers, one containing $95 \% \mathrm{O}_{2}-5 \% \mathrm{CO}_{2}$, the other containing $95 \% \mathrm{~N}_{2}-5 \% \mathrm{CO}_{2}$. The tonometers were then sealed and rotated at $37^{\circ} \mathrm{C}$. for one-half hour, after which samples were taken under oil and prepared for analysis as before.

(b) Long term in vitro experiments. In order to investigate changes in SCA red cell [K] over a longer period of time, a different technique was employed for several reasons: 1) SCA red cells kept in the de-oxygenated state for several hours become extremely viscous and 
TABLE I

Results of typical experiments on one normal subject and one patient with SCA

Each blood sample was incubated for one-half hour in the oxygenated and de-oxygenated state.

\begin{tabular}{|c|c|c|c|c|c|c|c|c|c|c|c|c|c|}
\hline \multirow{2}{*}{ Subject } & \multicolumn{2}{|c|}{ Gas } & \multicolumn{2}{|c|}{ Blood gas } & \multicolumn{5}{|c|}{ Red blood cell } & \multicolumn{4}{|c|}{ Plasma } \\
\hline & $\mathrm{DO}_{2}$ & $\mathrm{pCO}_{2}$ & $\mathrm{O}_{2}$ & $\mathrm{CO}$ & $\mathrm{Na}$ & $\mathbf{K}$ & $\mathrm{Na}+\mathrm{K}$ & $\mathrm{H}_{2} \mathrm{O}$ & $\mathrm{pH}$ & $\mathrm{Na}$ & $\mathbf{K}$ & $\mathrm{Na}+\mathrm{K}$ & $\mathrm{pH}$ \\
\hline Normal & $\begin{array}{c}m m . H_{g} \\
215 \\
12\end{array}$ & $\begin{array}{c}m m . H_{8} \\
45 \\
42\end{array}$ & $\begin{array}{c}\text { ool. \% } \\
22.8 \\
3.4\end{array}$ & $\begin{array}{c}\text { nol. \% } \\
46 \\
50\end{array}$ & $\begin{array}{c}m E q . / l \\
11 \\
11\end{array}$ & $\begin{array}{c}m E q . / l . \\
98 \\
96\end{array}$ & $\begin{array}{c}m E_{q .} / l \\
109 \\
107\end{array}$ & $\begin{array}{c}\% \\
66.0 \\
66.0\end{array}$ & $\begin{array}{l}\text { calc. } \\
7.19 \\
7.25\end{array}$ & $\begin{array}{c}m E q . / l \\
136 \\
136\end{array}$ & $\begin{array}{c}m E q . / l . \\
3.7 \\
3.7\end{array}$ & $\begin{array}{c}m E_{q} / l \\
140 \\
140\end{array}$ & $\begin{array}{l}\text { calc. } \\
7.37 \\
7.44\end{array}$ \\
\hline $\begin{array}{c}\text { Sickle cell } \\
\text { anemia }\end{array}$ & $\begin{array}{r}237 \\
8\end{array}$ & $\begin{array}{l}42 \\
41\end{array}$ & $\begin{array}{l}8.5 \\
0.4\end{array}$ & $\begin{array}{l}50 \\
51\end{array}$ & $\begin{array}{l}27 \\
40\end{array}$ & $\begin{array}{l}83 \\
60\end{array}$ & $\begin{array}{l}110 \\
100\end{array}$ & $\begin{array}{l}64.1 \\
63.4\end{array}$ & $\begin{array}{l}7.19 \\
7.19\end{array}$ & $\begin{array}{l}134 \\
133\end{array}$ & $\begin{array}{l}4.5 \\
7.0\end{array}$ & $\begin{array}{l}139 \\
140\end{array}$ & $\begin{array}{l}7.37 \\
7.38\end{array}$ \\
\hline
\end{tabular}

difficult to pipette, 2) heparinized SCA blood in a Barcroft tonometer rotated at $37^{\circ} \mathrm{C}$. for 24 hours shows considerable hemolysis, 3 ) the vigorous centrifugation used to separate red cells and plasma might conceivably affect the results.

Forty ml. of fresh heparinized venous SCA blood were placed in a flask containing $60 \mathrm{ml}$. of a bicarbonatephosphate buffered electrolyte solution, $(\mathrm{pH} 7.4 ;[\mathrm{K}]=$ $4.4 \mathrm{mEq} . / 1$; $[\mathrm{Na}]=135 \mathrm{mEq} . / 1$ ) containing $4.0 \mathrm{gm} . / 1$. of glucose. This solution is known to maintain normal hu-

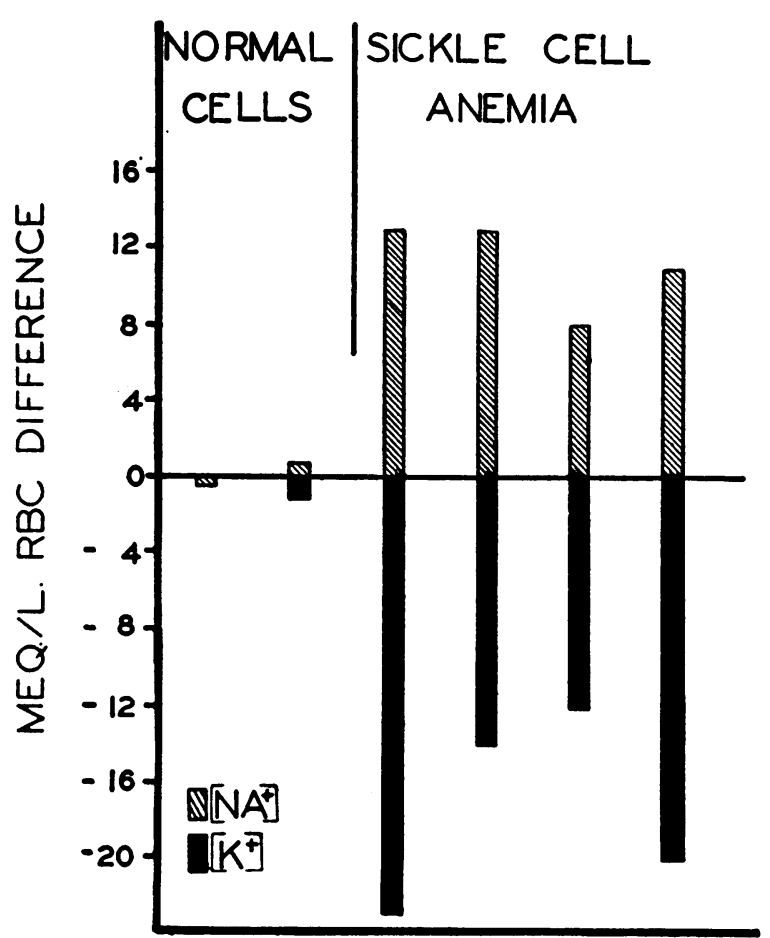

Fig. 1. Experiments on Two Normal Subjects and Four Patients with SCA-Each Blood Sample INCUBated For ONe-Half Hour in the OXygenated and De-oxygenated State

Each bar represents the difference between oxygenated and de-oxygenated red cell sodium or potassium concentration. man red cells in a relatively stable state for 48 hours (7). In our experiments visible hemolysis was present in only one sample and then was barely detectable by the naked eye. Twenty-five $\mathrm{ml}$. of the resultant diluted blood were placed in each of four Parafilm sealed Erlenmeyer flasks with open side-arms to allow gas flow. Ninety-five $\% \mathrm{O}_{2}-$ $5 \% \mathrm{CO}_{2}$ was flushed through the flasks which were then rocked $12 \times / \mathrm{min}$. through an arc of $30-40^{\circ}$ in a water bath at $37^{\circ} \mathrm{C}$. for one-half hour. One flask was then taken from the bath and the diluted blood removed under oil. Either $95 \% \mathrm{O}_{2}-5 \% \mathrm{CO}_{2}$ or $95 \% \mathrm{~N}_{2}-5 \% \mathrm{CO}_{2}$ was flushed through the remaining three flasks which were then rocked in the bath as before. Samples of diluted blood were taken under oil at four, 12, and 24 hours. Hematocrit was determined on all samples by centrifugation at $800 \mathrm{~g}$. for one hour. $\mathrm{K}$ in diluted blood and diluted plasma was measured by flame photometer, as before. Red cell [K] was calculated from these data by the following formula : $\mathrm{K}_{\mathrm{c}}=1 / \gamma \mathrm{K}_{\mathrm{b}}-\mathrm{K}_{\mathrm{p}}(1-\gamma)$ when $\mathrm{K}_{\mathrm{c}}=\operatorname{red}$ cell $[\mathrm{K}], \mathrm{K}_{\mathrm{b}}$ $=$ diluted blood $[\mathrm{K}], \mathrm{K}_{\mathrm{p}}=$ diluted plasma $[\mathrm{K}]$, and $\boldsymbol{\gamma}=$ hematocrit corrected for incomplete packing (8).

(c) In vivo experiments. In order to investigate the initial phase of the cation changes in vivo, $20 \mathrm{ml}$. samples of blood were drawn simultaneously, under oil, from the antecubital vein and opposite brachial or femoral artery. Drawing of the venous sample was preceded by five to $\mathbf{3 0}$ minutes of venous congestion produced by a blood pressure cuff at $90 \mathrm{~mm}$. $\mathrm{Hg}$. The samples were immediately heparinized and centrifuged under oil at $14 \times 10^{3} \mathrm{~g}$. for one hour. Samples of red cells and plasma were analyzed for $\mathrm{K}, \mathrm{Na}$, and water as before.

\section{RESULTS}

\section{(a) Short-term experiments in vitro}

In one experiment (Table I) typical of four with SCA red cells, [K] was about $23 \mathrm{mEq} . / 1$. $\mathrm{RBC}$ less and [Na] about $13 \mathrm{mEq} . / 1 . \mathrm{RBC}$ more, in the de-oxygenated than in the oxygenated state. This loss of $\mathrm{K}$ and gain of $\mathrm{Na}$ was not evident upon de-oxygenation of normal cells. Even in the oxygenated state, SCA red cell $[\mathrm{K}]$ was somewhat less and $[\mathrm{Na}]$ somewhat more than the values in nor- 


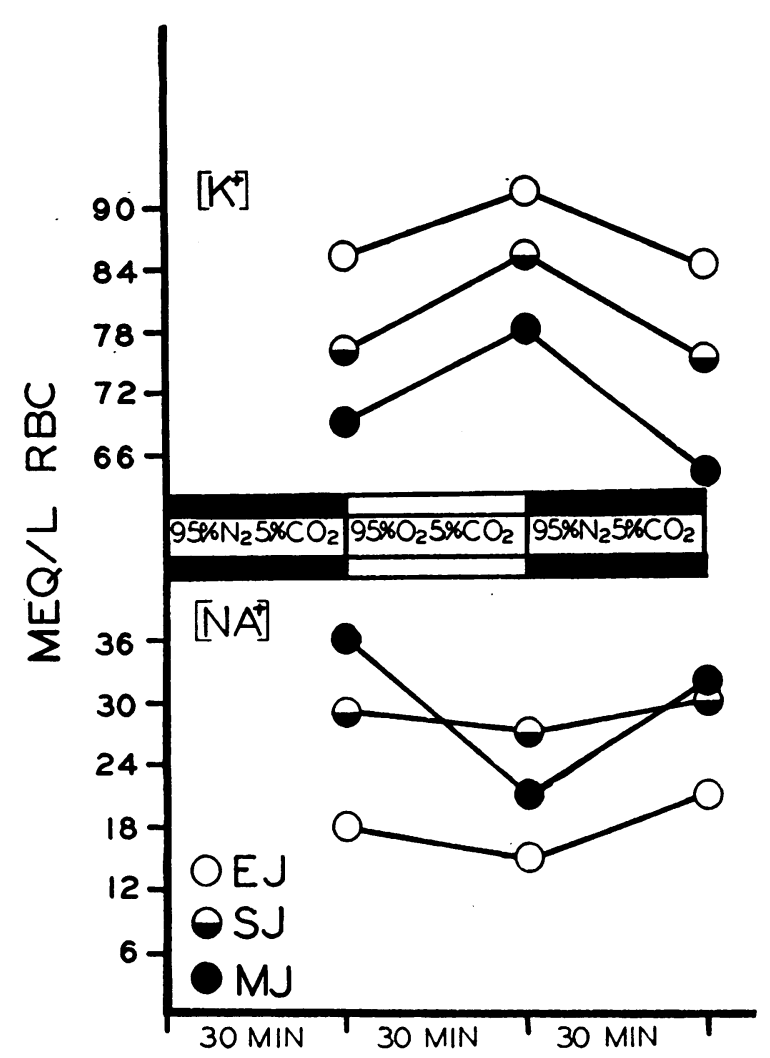

Fig. 2. Experiments on Three Patients with SCA -Each Blood Sample Incubated Consecutively for One-Half Hour in the De-oxygenated, Oxygenated, and De-oxygenated State

mal red cells. Since the loss of $K$ exceeded the gain of $\mathrm{Na}$ by de-oxygenated SCA red cells, the sum of $[\mathrm{K}]+[\mathrm{Na}]$ was slightly less in the deoxygenated than in the oxygenated state.

The water content of SCA red cells was slightly less than the value for normal red cells in the oxygenated state. De-oxygenation resulted in a slight fall in SCA red cell water content but did not affect normal red cell water content. Since the water content of de-oxygenated SCA red cells was, if anything, slightly less than the oxygenated value, it is unlikely that increased plasma contamination due to incomplete packing of the sickled de-oxygenated cells caused the observed reduced [K] and increased [ $\mathrm{Na}$ ] in these cells. $\mathrm{pH}$ as calculated by the method of Henderson (9) was essentially the same in normal and SCA red cells in oxygenated and de-oxygenated states. The Donnan $r$ value for $\mathrm{H}^{+}$was assumed to be the same for normal and SCA blood (10).
Figure 1 presents a graphic summary of data obtained from four SCA patients and two normal subjects. The results qualitatively confirmed all the findings described above for a single experiment. The blood of every SCA patient studied showed significantly less red cell $\mathrm{K}$ and more $\mathrm{Na}$ in the de-oxygenated than in the oxygenated state. These differences were not present in eight experiments on two normal subjects.

Figure 2 presents data which demonstrate the reversibility of the $\mathrm{K}$ loss and $\mathrm{Na}$ gain of previously de-oxygenated SCA red cells upon re-oxygenation. In experiments on three SCA patients, the mean rates of $\mathrm{K}$ gain by re-oxygenated and $\mathrm{K}$ loss by de-oxygenated red cells were both about 20 $\mathrm{mEq} . / \mathrm{l}$. RBC/hr. The mean rates of $\mathrm{Na}$ loss by re-oxygenated and gain by de-oxygenated red cells were both about $14 \mathrm{mEq} . / 1 . \mathrm{RBC} / \mathrm{hr}$.

Figure 3 shows that $\mathrm{CO}$ blocked the $\mathrm{K}$ loss and $\mathrm{Na}$ gain by de-oxygenated SCA red cells. $\mathrm{CO}$ did not affect the cation concentrations of normal red

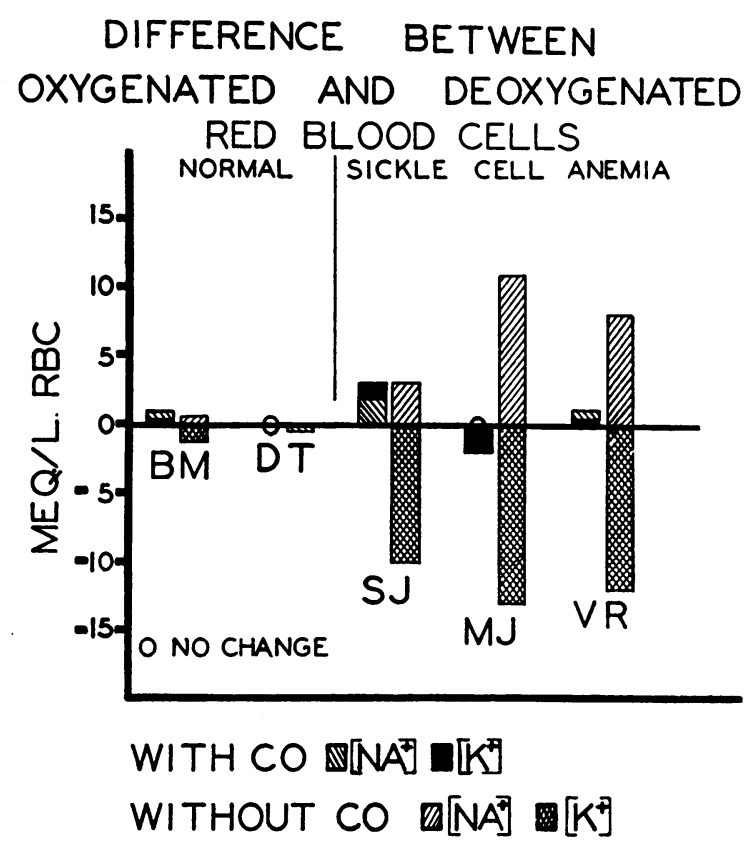

Fig. 3. Experiments on Two Normal Subjects and Three Patients with SCA-Each Blood Sample INCubated for One-Half Hour in 95\% $\mathrm{O}_{2}$ and $95 \% \mathrm{~N}_{2}$, WITH AND WIThout PRE-exposure to $25 \% \mathrm{CO}$

The bar on the left of each pair represents the difference between oxygenated and de-oxygenated red cell sodium or potassium concentration with pre-exposure to CO. The bar on the right of each pair represents the same quantity without pre-exposure to $\mathrm{CO}$. 
cells. Thus, hypoxia per se does not cause the $\mathrm{K}$ $\mathrm{Na}$ exchange observed in de-oxygenated SCA red cells.

\section{(b) Long-term experiments in vitro}

In the experiments with slow gentle shaking (see Methods) de-oxygenated SCA red cells continued to lose $\mathrm{K}$ for at least 24 hours (Figure 4 ). $\mathrm{K}$ loss from oxygenated SCA red cells was small and irregular in the two cases studied. The rate of $\mathrm{K}$ loss during the first four hours from de-oxygenated SCA red cells in this system was about 4 $\mathrm{mEq} . / 1$. RBC/hr. The rate of loss decreased with time but was still appreciable between 12 and 24 hours after the start of the experiment. In a system identical with that employed here Raker and his associates (7) working with normal cells did not observe accelerated $\mathrm{K}$ loss upon de-oxygenation.

\section{(c) Short-term experiments in vivo}

Figure 5 shows the cation difference in four SCA patients between red cells from congested

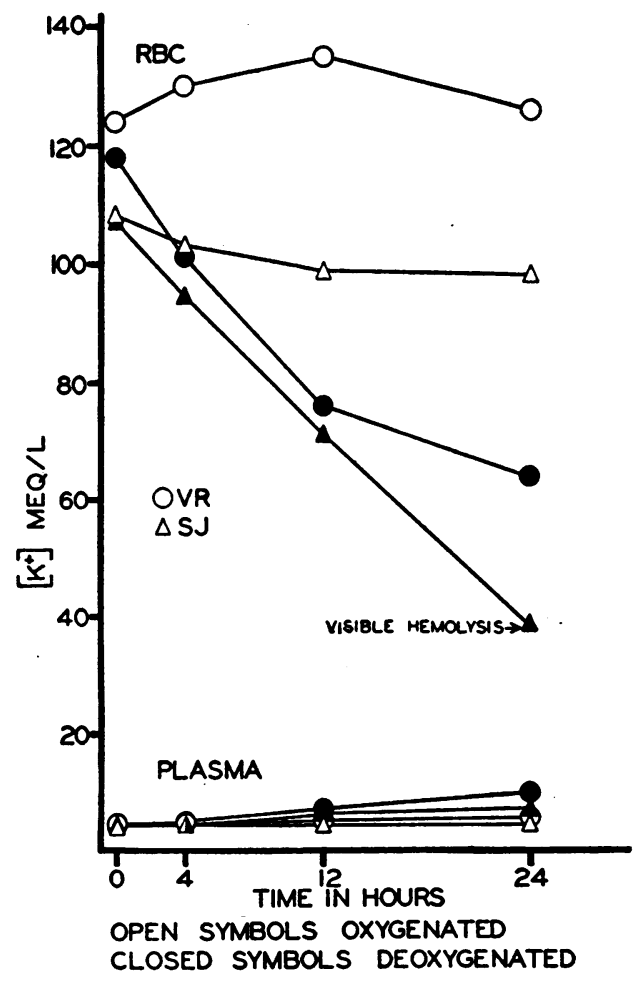

Fig. 4. Experiments on Two Patients with SCAEach Sample of Diluted Blood Incubated for 24 Hours in the Oxygenated and De-oxygenated State

The de-oxygenated 24-hour sample of SJ showed hemolysis just detectable by the naked eye.

\section{AV DIFFERENCE IN RBC}

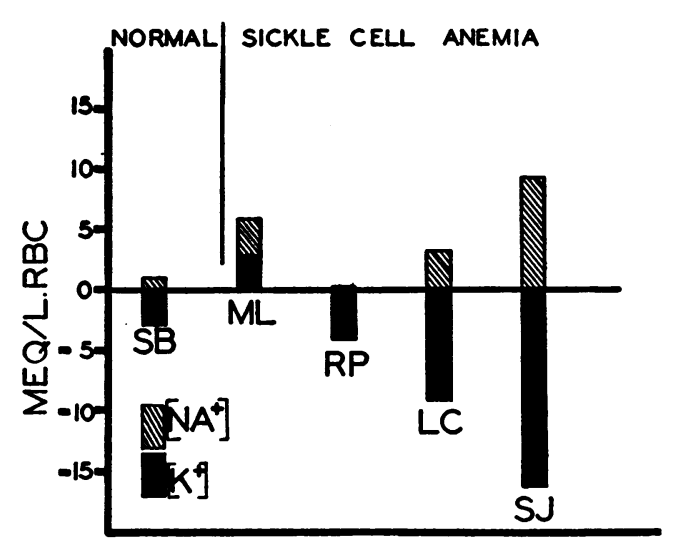

Fig. 5. Experiments on One Normal Subject and Four Patients with SCA-Each Bar Representing the Arteriovenous Difference in Red Cell Na or K Concentration

veins and arterial red cells. In general, venous red cell $[\mathrm{K}]$ was less and the $[\mathrm{Na}]$ more than the arterial values. The $\mathrm{A}-\mathrm{V}$ differences varied from a maximum of $-17 \mathrm{mEq}$. $\mathrm{K} / \mathrm{l}$. $\mathrm{RBC}$ and $+9 \mathrm{mEq}$. $\mathrm{Na} / \mathrm{l} . \mathrm{RBC}$ in one patient to a minimum of +3 $\mathrm{mEq} . \mathrm{K} / \mathrm{l} . \mathrm{RBC}$ and $0 \mathrm{mEq} . \mathrm{Na} / \mathrm{l} . \mathrm{RBC}$ in another. There was no $A-V$ difference in plasma $[K]$ so that we were unable to produce experimentally the clinically observed elevation of venous plasma $[\mathrm{K}]$. In the normal subject, $\mathrm{A}-\mathrm{V}$ differences in red cell and plasma $[\mathrm{K}]$ and $[\mathrm{Na}]$ were small.

\section{DISCUSSION}

Human red cells are known to lose $\mathrm{K}$ and gain $\mathrm{Na}$ on exposure to cold (11), X-rays (12), iodoacetate (13) and fluoride (13-15), in the absence of glucose $(14,15)$, and possibly upon infestation with malarial parasites (16). Ponder describes red cell $\mathrm{K}$ loss and $\mathrm{Na}$ uptake prior to hemolysis in a variety of in vitro hemolytic systems (17). The mechanism of such "prolytic" $\mathrm{K}-\mathrm{Na}$ exchange is obscure. The electrolyte shift which we found during hypoxia is, in our experience, unique to SCA and possibly sickle cell trait red cells. Whether this process is also "prolytic" is beyond the scope of this paper.

The initial rate of $\mathrm{K}$ loss from SCA red cells deoxygenated in a Barcroft tonometer (about 20 $\mathrm{mEq} . / 1$. RBC/hr.) was considerably faster than the value for SCA red cells de-oxygenated in an 
Erlenmeyer flask (about $4 \mathrm{mEq} . / \mathrm{RBC} / \mathrm{hr}$.). This difference was perhaps due to the slower rate of agitation or of equilibration of blood with gas phase in the latter system. During at least the first one-half hour of de-oxygenation the $\mathrm{K}$ loss could be reversed by re-oxygenation. In this circumstance, $\mathrm{K}$ uptake also occurred at an initial rate of about $20 \mathrm{mEq} . / 1$. RBC/hr. Since these rates of net $K$ uptake and loss were considerably faster than the rate of turnover of $\mathrm{K}$ in normal red cells in the steady state $(2 \mathrm{mEq} . / 1 . \mathrm{RBC} / \mathrm{hr}$.) (7, 18 ), it is probable that under certain conditions $K$ turnover in SCA red cells is considerably faster than in normal red cells. Experiments are now in progress to determine the effect of variations in temperature, concentration gradient, etc. on the rates of net $\mathrm{K}$ and $\mathrm{Na}$ transfer and to measure with appropriate isotopes the rate of turnover of these ions in SCA red cells.

Why do these electrolyte changes occur in deoxygenated SCA red cells but not in normal cells? Two general hypotheses are plausible:

(1) $\mathrm{K}-\mathrm{Na}$ exchange is due to an abnormality in SCA plasma. For example, "prolytic" ion exchange as described by Ponder is particularly large in hemolytic systems containing bile salts. Most SCA patients were slightly jaundiced but accurate determinations were not made of the concentration of bile salts in their plasma. It does not seem possible that plasma bile salts per se cause the cation exchange observed in SCA red cells because (a) it is unlikely that reduction in $\mathrm{pO}_{2}$ would accelerate such a process, and $(b)$ red cells taken from a patient with severe obstructive jaundice due to carcinoma of the head of the pancreas did not lose $\mathrm{K}$ or gain $\mathrm{Na}$ during 24 hours of incubation at $37^{\circ} \mathrm{C}$. in the oxygenated or de-oxygenated state. Since the shift occurred in de-oxygenated SCA red cells suspended in diluted plasma and (in one experiment) Ringer's solution, evidence for a plasma abnormality responsible for the process is at present lacking.

(2) $\mathrm{K}-\mathrm{Na}$ exchange is due to an abnormality in SCA red cells. The most obvious difference between the responses of normal and SCA red cells to hypoxia is the occurrence of sickling in the latter. Several facts suggest that $\mathrm{K}$ loss and $\mathrm{Na}$ uptake by de-oxygenated SCA red cells is intimately associated with the process of sickling : (a) CO prevents both sickling and $\mathrm{K}-\mathrm{Na}$ exchange in de-oxy- genated SCA red cells, (b) both processes begin almost immediately after de-oxygenation of SCA blood.

What is the mechanism relating the processes of sickling and $\mathrm{K}-\mathrm{Na}$ exchange in SCA red cells? The change of shape and probable mechanical distortion of the red cell membrane in the sickled state are obvious. These changes could accelerate the diffusion of $\mathrm{K}$ and $\mathrm{Na}$ in the direction of their concentration gradients. In addition, recently demonstrated differences between ionic (19), and physical $(3,12,20)$ properties of SCA and normal hemoglobin may be related to cation exchange in sickled SCA red cells. Specifically, the work of Harris (3) and of Perutz and Mitchison (20) suggests that unsaturated SCA hemoglobin is in a crystalline or para-crystalline state. It is not yet clear whether the observed changes in cation composition of sickled SCA red cells are primarily related to the physical properties of desaturated SCA hemoglobin or to alteration of the SCA red cell membrane incident to the sickle shape.

\section{SUM MARY AND CONCLUSIONS}

1. In the de-oxygenated but not in the oxygenated state, red cells from patients with sickle cell anemia (SCA) begin to lose $\mathrm{K}$ and gain $\mathrm{Na}$ almost immediately and continue to do so for at least 24 hours. This process does not occur in deoxygenated normal red cells.

2. During the first half hour at least, $\mathrm{K}-\mathrm{Na}$ exchange in de-oxygenated SCA red cells can be reversed by re-oxygenation.

3. $\mathrm{K}$ loss and $\mathrm{Na}$ gain by red cells does not occur in the absence of $\mathrm{O}_{2}$ if sickling is prevented by CO.

\section{REFERENCES}

1. Erickson, B. N., Williams, H. H., Hummel, F. C., Lee, P., and Macy, I. G., The lipid and mineral distribution of the serum and erythrocytes in the hemolytic and hypochromic anemias of childhood. J. Biol. Chem., 1937, 118, 569.

2. Hahn, E. V., and Gillespie, E. B., Sickle cell anemia : report of a case greatly improved by splenectomy. Experimental study of sickle cell formation. Arch. Int. Med., 1927, 39, 233.

3. Harris, J. W., Studies on the destruction of red blood cells. VIII. Molecular orientation in sickle cell hemoglobin solutions. Proc. Soc. Exper. Biol. \& Med., 1950, 75, 197. 
4. Berry, J. W., Chapell, D. G., and Barnes, R. B., Improved method of flame photometry. Indust. \& Engin. Chem. (Analyt Ed.), 1946, 18, 19.

5. Scholander, P. F., Analyzer for accurate estimation of respiratory gases in one-half cubic centimeter samples. J. Biol. Chem., 1947, 167, 235.

6. Van Slyke, D. D., and Neill, J. M., The determination of gases in blood and other solutions by vacuum extraction and manometric measurement. J. Biol. Chem., 1924, 61, 523.

7. Raker, J. W., Taylor, I. M., Weller, J. M., and Hastings, A. B., Rate of potassium exchange of the human erythrocyte. J. Gen. Physiol., 1950, 33,691 .

8. Millar, W. G., Observations on the haematocrite method of measuring the volume of erythrocytes. Quart. J. Exper. Physiol., 1925, .15, 187.

9. Henderson, L. J., Blood, a Study in General Physiology. Yale Univ. Press, New Haven, 1928.

10. Dill, D. B., Edwards, H. T., and Consolazio, W. V., Blood as a physico-chemical system. XI. Man at rest. J. Biol. Chem., 1937, 118, 635.

11. Smith, M. E., Tuthill, E., Drew, C. R., and Scudder, J., Studies in blood preservation. Some effects of carbon dioxide. J. Biol. Chem., 1940, 133, 499.

12. Sheppard, C. W., and Beyl, G. E., Cation exchange in mammalian erythrocytes. III. The prolytic effect of x-rays on human cells. J. Gen. Physiol., 1951, 34, 691.
13. Wilbrandt, W., A relation between the permeability of the red cell and its metabolism. Tr. Faraday Soc., 1937, 33, 956.

14. Harris, J. E., The influence of the metabolism of human erythrocytes on their potassium content. J. Biol. Chem., 1941, 141, 579.

15. Danowski, T. S., The transfer of potassium across the human blood cell membrane. J. Biol. Chem., 1941, 139, 693.

16. Overman, R. R., Hill, T. S., and Wong, Y. T., Physiological studies in the human malarial host. I. Blood, plasma, extracellular fluid volumes and ionic balance in therapeutic $P$. vivax and $P$. falciparum infections. J. Nat. Malaria Soc., 1949, 8, 14.

17. Ponder, E., Hemolysis and Related Phenomena. Grune \& Stratton, New York, 1948.

18. Sheppard, C. W., and Martin, W. R., Cation exchange between cells and plasma of mammalian blood. I. Methods and application to potassium exchange in human blood. J. Gen. Physiol., 1950, 33, 703.

19. Pauling, L., Itano, H. A., Singer, S. J., and Wells, I. C., Sickle cell anemia, a molecular disease. Science, 1949, 110, 543.

20. Perutz, M. F., and Mitchison, J. M., State of haemoglobin in sickle-cell anaemia. Nature, 1950, 166, 677. 